SANTOS, CP; NOBOA, CS; MARTINEZ, M; CARDOSO, JC; SALA, FC. 2021. Morphological evaluation of lettuce genotypes grown under hydroponic system. Horticultura Brasileira 39: 312-318. DOI: http://dx.doi.org/10.1590/s0102-0536-20210311

\title{
Morphological evaluation of lettuce genotypes grown under hydroponic system
}

\author{
Camila P dos Santos ${ }^{1} \mathbb{D}$; Caio S Noboa ${ }^{1} \mathbb{D}$; Marcela Martinez ${ }^{1} \mathbb{D}$; Jean Carlos Cardoso $^{1} \mathbb{D}$; Fernando Cesar \\ Sala ${ }^{1} \mathbb{D}$
}

${ }^{1}$ Universidade Federal de São Carlos (UFSCar), Departamento de Biotecnologia e Produção Vegetal e Animal, Araras-SP, Brasil; camilah_ peixoto@hotmail.com; caiosalvador@hotmail.com; marcela.ciarlomartinez@hotmail.com; jeancardoso@ufscar.br; fcsala@ufscar.br

\begin{abstract}
Crispleaf lettuce, which is a light green leaf lettuce, is the most popular leafy vegetable in Brazil. However, it is relevant to evaluate agronomic traits of lettuce with more intense green color leaves considering the increase in consumer demand. Thus, the aim of this study was to evaluate lettuce genotypes about the different chlorophyll contents and correlate with green mass production in a hydroponic system. Ten lettuce inbred lines and two cultivars (Vanda and Luiza) were evaluated for agronomic traits and chlorophyll contents in leaves. A randomized block design with four replicates was used. The chlorophyll content was variable among the genotypes, ranging from 43.3 (Luiza) to 20.8 (Vanda). The genotypes with the highest chlorophyll content were those who showed the lowest mass production, but no correlations were found between these variables, though.
\end{abstract}

Keywords: Lactuca sativa, chlorophyll, hydroponics, leafy vegetable, pigment, mass production.

\section{RESUMO}

Avaliação morfológica de genótipos de alface em sistema hidropônico

A alface do tipo crespa, com folhas de coloração verde clara, é a hortaliça folhosa preferida no Brasil. Contudo, é relevante avaliar características agronômicas de alface com coloração verde mais intensa considerando o aumento da demanda de consumo. Dessa forma objetivou-se avaliar genótipos de alface com diferentes teores de clorofila e correlacionar com a produção de massa verde, em sistema hidropônico. Dez linhagens de alface e duas cultivares (Vanda e Luiza) foram avaliadas para características agronômicas e teores de clorofila nas folhas, em delineamento de blocos ao acaso com quatro repetições. O teor de clorofila foi variável entre os genótipos, variando de 43,3 (Luiza) a 20,8 (Vanda). Os genótipos que apresentaram maior teor de clorofila foram os que apresentaram menor produção de massa, mas não foi encontrada correlação entre essas variáveis.

Palavras-chave: Lactuca sativa, clorofila, hidroponia, hortaliça folhosa, pigmento, produção de massa.

\section{Received on September 4, 2020; accepted on July 7, 2021}

L ettuce is a vegetable of great economic importance; the market for seeds and seedlings is estimated around US\$ 17.07 and US\$ 52.48 million per year, with a production area of 91,172 ha, average productivity of $18.6 \mathrm{t} \mathrm{ha}^{-1}$ year ${ }^{-1}$ and revenue of US\$384.63 million year ${ }^{-1}$ (Confederação da Agricultura e Pecuária do Brasil, 2017). Lettuce is grown intensively and under different productive systems, being the hydroponic system the one which stands out. This system has been increasing in the last decades and promotes production all year long, favors management, maximizes the use of inputs, allows a partial control of environmental adverse conditions, and also it is more convenient for consumers as it provides greater cleanliness in the finished product. This system allows an average water consumption of $4 \mathrm{~L}$ plant $^{-1}$ cycle $^{-1}, 90 \%$ lower value when compared to conventional cultivation, about $25 \mathrm{~L}_{\text {plant }}{ }^{-1}$ cycle $^{-1}$ (Purquerio et al., 2018). In Brazil, about 2000 ha are covered by leafy vegetables hydroponically cultivated, and the hydroponic system is used in one in five municipalities, being the state of São Paulo the biggest producer (Lima et al., 2018).

Crispleaf lettuce is the favorite variety in Brazilian vegetable market. Its leaves are flabellate, tender, consistent and flexible, with wavy edges, predominance of light green color, early cycle and no head formation.
A great variation among the marketable cultivars in relation to shape, size and color is verified (Sala \& Costa, 2012). When evaluating new lettuce inbred lines, several traits should be taken into consideration, such as plant structure, productivity, number of leaves, leaf shape and plant color. A coloring which best pleases and draws consumers' attention, as well as longer shelf life, is important to meet the needs of an increasingly dynamic and demanding market (Fontana et al., 2018).

In lettuce breeding program, most researches have been trying to incorporate resistance or tolerance to some diseases or aim to tropicalize some cultivars for early-bolting tolerance. On the other hand, researches aiming at a 
greener-colored leaf lettuce have been the target of vegetable breeding program at UFSCar. Researchers have been searching for a cultivar which shows a more intense green color (higher chlorophyll content) and shiny leaves (Sala, 2011; Sala \& Costa, 2014).

Chlorophyll is a pigment and the main photoreceptor of the photosynthetic apparatus. It has two main types in vascular plants, chlorophyll a and chlorophyll $\mathrm{b}$, which are generally in a 3:1 ratio, respectively (Bhatla \& Manju, 2018).

Chlorophyll has potential health benefits, such as antioxidant, antiinflammatory, antimutagenic and anticancer activity (Ferruzzi \& Blakeslee, 2007). Few researches on chlorophyll, and its health benefits, can be found in literature; the chlorophyll present in leafy vegetable leaves has a direct influence on their color and on consumer preference, though (Silva $e t$ al., 2016).

The leaf color is one important qualitative trait and is defined by an instrumental color analysis using a colorimeter. According to Filgueira (2008), lettuce shows several shades of green, ranging from yellowish green (light green) to dark green or purple. In Brazil, the yellowish green crispy lettuce stands out among the marketable cultivars (Sala \& Costa, 2012).

The color is influenced by the pigments existing in leaves themselves. Chlorophyll is responsible for the green color and that, together with the carotenoids, which are responsible for the yellow, red or orange colors, give different shades of colors to vegetables (Ferruzzi \& Blakeslee, 2007). Plants which perform oxygen photosynthesis have chlorophyll a and accessory pigments such as chlorophyll $\mathrm{b}$, and other types of chlorophylls and pigments (Taiz et al., 2017). The photosynthetic activity performed by the plant is related to chlorophyll, which has a high correlation with the content of carotenoids (Cassetari et al., 2015), directly influencing the leaf color and consumer preference (Silva et al., 2016).

Most plants have chlorophyll a and $\mathrm{b}$, the sum of the two corresponding to total chlorophyll. Plants which develop in environments with more luminosity have higher chlorophyll a content and plants in shaded environments have higher chlorophyll b content. This is explained by the fact that chlorophyll $b$ degrades more easily in the presence of light. Thus, in low-light environments, a higher proportion of chlorophyll $b$ can be verified; this chlorophyll b can capture energy at other wavelengths and transfers it to chlorophyll a, which effectively acts in photosynthesis reactions (Lima et al., 2011). Photosynthesis performed by plants depends on chlorophyll a, which is responsible for capturing mainly red and blue light (Johkan et al., 2010). Plants with higher content of chlorophyll tend to show higher photosynthetic rate, however, it does not mean greater mass accumulation (Wang et al., 2016).

Rosa et al. (2014), evaluating the green and purple mimosa lettuce hydroponically cultivated, verified that the green mimosa lettuce showed lower chlorophyll contents, its fresh mass production was higher, though. Cardoso et al. (2018), evaluating lettuce cultivars in protected environment, verified that the head lettuce showed higher chlorophyll content, it was not the cultivar which showed the highest mass production, though. However, there are limited studies associated to the content of chlorophylls in lettuce leaves with their mass productivity, which could be used for breeders in the selection and development of more efficient plants. Thus, the aim of this study was to evaluate the performance of lettuce genotypes with different colors and their association with different chlorophyll contents under hydroponic system and verify its relation with the mass production.

\section{MATERIAL AND METHODS}

The lettuce seedlings were produced in a commercial nursery (IBS Mudas), in the municipality of Piracicaba-SP $\left(22^{\circ} 37^{\prime} 46^{\prime}\right.$ 'S , 47 $36^{\prime} 07^{\prime \prime} \mathrm{W}, 547 \mathrm{~m}$ altitude), from October to November, 2018. Sowing was performed in 128 cells trays with a volume of $27 \mathrm{~cm}^{3}$ cell $^{-1}$, filled with coconut fiber substrate (Amafibra ${ }^{\circledR}$ ). We used 10 inbred lines $(09,27,38,47,110,142,167,195$, 253 and 288) of crispleaf lettuce of the breeding program of UFSCar. This type of lettuce was chosen for presenting different color of leaves. The cultivars Vanda (Sakata $\left.{ }^{\circledR}\right)$ and Luiza (Feltrin $\left.{ }^{\circledR}\right)$ were used as controls for all the studied attributes and for the high contrast in relation to leaf color. Luiza is a lettuce variety with roman-style, dark green leaves (L 47.63, $a^{*}-13.48$ and $b^{*} 36.52$ ) and Vanda is a lettuce variety with crisp leaves and light green coloration (L 56.59, $a^{*}-11.89$ and $b^{*} 37.11$ ).

After reaching three true leaves, approximately 30 days after sowing, the seedlings were transplanted directly to definitive hydroponic profiles (laminar flow of nutrients) in an experimental area of Universidade Federal de São Carlos, in Araras-SP (22 $21^{\prime} 25^{\prime}$ 'S, $47^{\circ} 23^{\prime} 03^{\prime \prime} \mathrm{W}, 646 \mathrm{~m}$ altitude). The structure consisted of a self-priming pump ( $1 \mathrm{hp}$ engine, maximum flow of $3600 \mathrm{~L}^{\text {hour }}{ }^{-1}$ ), 5000-liter capacity reservoir, red screen covering $(30 \%$ shading), lateral walls covered with red roof measuring 40 meters long, 48 $\mathrm{m}$ wide and 1.95 meter height ceiling. The authors used seven 75-mm-profiles ( $7.5 \mathrm{~cm}$ height and $10 \mathrm{~cm}$ diameter, each profile) with $15 \mathrm{~m}$ in length and spacing of $0.30 \mathrm{~m}$ between profiles and $0.25 \mathrm{~m}$ between plants. Bench slope was $6 \%$.

The experimental design was completely randomized blocks, with twelve treatments (inbred lines: 09, $27,38,47,110,142,167,195,253$ and 288 and cultivars Vanda and Luiza) and four replicates, with 30 plants per plot, totalizing 1440 plants in the experiment. The trays were placed on four hydroponic benches (each bench was considered a block); the useful plants were the five central ones of each plot, discarding the border. Nutrient solution (Furlani, 1999) was used for conducting the plants. The circulation scheme of the nutrient solution was every 15 minutes during the day (from 6 a.m. to 6 p.m.) and 15 minutes every 4 hours during the night.

Thirty days after planting, the authors evaluated the chlorophyll contents ( $\mathrm{a}, \mathrm{b}$ and total), plant height, 
root length, number of leaves, shoot fresh mass, stem length, stem diameter, root fresh mass, shoot and root dry mass. For all evaluations, five plants per plot were used. In order to evaluate the chlorophyll content, the authors evaluated one leaf per plant, the longest leaf was considered, the most developed but not the senescent leaf. Falker chlorophyll meter (ClorofiLOG CFL1030) was used for the evaluation, obtaining the instantaneous and nondestructive reading of the chlorophyll a and $b$ contents of each treatment.

The plant height was measured from the base to the apex of the plant $\left(\mathrm{cm}\right.$ plant $\left.^{-1}\right)$. For the root length, we considered the base (insertion of stem and root) up to shoot tip $\left(\mathrm{cm} \mathrm{plant}^{-1}\right)$. For the number of leaves, all the leaves equal to or longer than $3-\mathrm{cm}$ were counted. The authors highlighted root system shoot to evaluate fresh masses in an electronic scale (Economic line next). We pre-dried the fresh mass in paper bags, left in the sun for a week and, then taken to a forced air circulation oven, at $65^{\circ} \mathrm{C}$ (M 035/Marconi) for three days, until reaching constant masses. Afterwards, the dry mass was obtained using a precision scale (Milesimal Bel Engineering). The stem length was measured from the stem base up to apical meristem $\left(\mathrm{cm} \mathrm{plant}^{-1}\right)$. The stem diameter was also measured using a caliper ( $\left.\mathrm{cm}_{\text {plant }}{ }^{-1}\right)$.

Data were analyzed using R Software (R Core Team, 2018), being submitted to variance analysis (ANOVA) and the variables with significant differences were determined by $\mathrm{F}$ test and then by the multiple comparisons test, ScottKnott at $5 \%$ significance $(\mathrm{p} \leq 0.05)$. A Pearson correlation matrix and principal component analysis (PCA) was performed to evaluate possible relationships among the measured variables.

\section{RESULTS AND DISCUSSION}

The types of lettuce which showed the highest shoot fresh mass per plant were the inbred lines 38, 195, 253 and the cultivar Vanda (Table 1), ranging from $264 \mathrm{~g}$ (Vanda) to $297 \mathrm{~g}$ plant $^{-1}$ (inbred line 38) with an average $54 \%$ higher compared to genotypes with lower values $(47,167$ and Luiza, Table 1). Lima et al. (2018), evaluating crispleaf lettuce Vanda, under hydroponic system, found similar results, presenting fresh mass around $300 \mathrm{~g} \mathrm{plant}^{-1}$ when harvested at 29 days after transplanting. In the actual study, the cultivars which showed the highest fresh mass, except the inbred line 195, were also those with the highest shoot dry mass, with an average $36 \%$ higher compared with inbred lines 47, 167 and Luiza (Table 1). In addition, there was verified superiority of $54 \%$ in fresh mass among cultivars which presents the highest and lowest fresh masses, considering that the values of dry mass ranged $36 \%$ in relation to the cultivars with the highest and lowest masses, suggesting that the inbred lines 38, 195, 253 and Vanda were able to retain more water. The cultivars with the highest dry mass, line 195 and those with the lowest dry mass presented, respectively, $20.9,23.4$ and $18.2 \mathrm{~g}$ of water per $\mathrm{g}$ of dry mass.

The authors observed that $64.8 \%$ of data variation is explained by PCA (Figure 1). The direction of the arrows indicates the correlation between the analyzed variables, so when they are parallel they have an indication of a positive relationship, when they are in the opposite direction, a negative relationship can be verified, that is, as one variable increases, the other decreases. When the arrows are perpendicular, no relationship between the variables is verified. Using PCA, the authors could observe that the shoot dry and fresh

Table 1. Shoot fresh mass (MFPA) $\left(\right.$ g plant $\left.^{-1}\right)$, shoot dry mass (MSPA) $\left(g_{\text {plant }}^{-1}\right)$, root fresh mass (MFR) $\left(\right.$ g plant $\left.^{-1}\right)$, root dry mass $($ MSR) $\left(\mathrm{g} \mathrm{plant}^{-1}\right)$, number of total leaves (NFT), plant height (AP) $\left(\mathrm{cm} \mathrm{plant}^{-1}\right)$, root length $(\mathrm{CR})\left(\mathrm{cm} \mathrm{plant}^{-1}\right)$, stem length $(\mathrm{CC})\left(\mathrm{cm} \mathrm{plant}^{-1}\right)$, stem diameter (DC) $\left(\mathrm{mm} \mathrm{plant}^{-1}\right)$ and chlorophyll a, chlorophyll b and total chlorophyll contents (Falker index) of lettuce inbred lines and cultivars (Vanda and Luiza) grown under hydroponic system. Araras, UFSCar, 2019.

\begin{tabular}{|c|c|c|c|c|c|c|c|c|c|c|c|c|}
\hline \multirow{2}{*}{$\begin{array}{l}\text { Genotypes } \\
9\end{array}$} & \multicolumn{2}{|c|}{ MFPA } & \multicolumn{2}{|c|}{ MSPA } & \multicolumn{2}{|c|}{ MFR } & \multicolumn{2}{|c|}{ MSR } & \multicolumn{2}{|c|}{ NFT } & \multicolumn{2}{|c|}{$\mathbf{A P}$} \\
\hline & 227.8 & $\mathrm{~b}$ & 11.4 & $\mathrm{~b}$ & 49.9 & $\mathrm{a}$ & 4.0 & & 35.4 & $\mathrm{a}$ & 25.8 & $\mathrm{a}$ \\
\hline 27 & 229.8 & $\mathrm{~b}$ & 10.9 & $\mathrm{~b}$ & 49.4 & $\mathrm{a}$ & 3.8 & $\mathrm{a}$ & 33.9 & $\mathrm{a}$ & 21.8 & $\mathrm{c}$ \\
\hline 38 & 297.0 & $\mathrm{a}$ & 13.8 & $\mathrm{a}$ & 51.3 & $\mathrm{a}$ & 3.9 & $\mathrm{a}$ & 28.1 & $\mathrm{c}$ & 24.7 & $\mathrm{~b}$ \\
\hline 47 & 186.4 & $\mathrm{c}$ & 10.1 & $\mathrm{c}$ & 41.3 & $\mathrm{~b}$ & 3.3 & $\mathrm{~b}$ & 25.5 & $\mathrm{c}$ & 20.9 & $d$ \\
\hline 110 & 236.1 & $\mathrm{~b}$ & 11.0 & $\mathrm{~b}$ & 53.9 & $\mathrm{a}$ & 4.1 & $\mathrm{a}$ & 25.6 & $\mathrm{c}$ & 22.8 & $\mathrm{c}$ \\
\hline 142 & 229.3 & $\mathrm{~b}$ & 11.5 & $\mathrm{~b}$ & 51.8 & $\mathrm{a}$ & 4.0 & $\mathrm{a}$ & 24.3 & $\mathrm{c}$ & 23.2 & $\mathrm{c}$ \\
\hline 167 & 169.9 & $\mathrm{c}$ & 8.6 & $\mathrm{c}$ & 51.4 & $\mathrm{a}$ & 4.1 & $\mathrm{a}$ & 21.1 & $\mathrm{~d}$ & 19.9 & $\mathrm{~d}$ \\
\hline 195 & 280.5 & $\mathrm{a}$ & 11.5 & $\mathrm{~b}$ & 50.1 & $\mathrm{a}$ & 3.6 & $\mathrm{a}$ & 20.4 & $\mathrm{~d}$ & 23.3 & $\mathrm{c}$ \\
\hline 253 & 289.5 & $\mathrm{a}$ & 12.4 & $\mathrm{a}$ & 48.1 & $\mathrm{a}$ & 3.9 & $\mathrm{a}$ & 25.1 & $\mathrm{c}$ & 23.1 & $\mathrm{c}$ \\
\hline 288 & 234.3 & $\mathrm{~b}$ & 11.1 & $\mathrm{~b}$ & 56.6 & $\mathrm{a}$ & 4.3 & $\mathrm{a}$ & 32.8 & $\mathrm{a}$ & 26.8 & $\mathrm{a}$ \\
\hline Vanda & 264.1 & $\mathrm{a}$ & 12.8 & $\mathrm{a}$ & 45.4 & $\mathrm{~b}$ & 3.4 & $\mathrm{~b}$ & 25.8 & $\mathrm{c}$ & 25.3 & $\mathrm{~b}$ \\
\hline Luiza & 193.3 & $\mathrm{c}$ & 9.9 & $\mathrm{c}$ & 41.9 & $\mathrm{~b}$ & 2.8 & $\mathrm{~b}$ & 30.2 & $\mathrm{~b}$ & 24.1 & $\mathrm{~b}$ \\
\hline CV (\%) & 9.2 & & 10.8 & & 8.6 & & 12.0 & & 7.9 & & 3.7 & \\
\hline
\end{tabular}


Table 1. continuation.

\begin{tabular}{lccccccccc}
\hline Genotypes & \multicolumn{1}{c}{ CR } & CC & DC & Clor a & Clor b & \multicolumn{2}{c}{ Total clor } \\
\hline 9 & 42.9 & $\mathrm{c}$ & $5.7 \mathrm{c}$ & $2.7 \mathrm{a}$ & 32.0 & $\mathrm{a}$ & $7.5 \mathrm{~b}$ & 39.5 & $\mathrm{a}$ \\
27 & $40.7 \mathrm{c}$ & $5.0 \mathrm{c}$ & $2.5 \mathrm{~b}$ & $30.1 \mathrm{~b}$ & $5.5 \mathrm{c}$ & 35.6 & $\mathrm{~b}$ \\
38 & $37.3 \mathrm{c}$ & $7.5 \mathrm{~b}$ & $2.4 \mathrm{c}$ & $24.1 \mathrm{c}$ & $4.5 \mathrm{c}$ & $28.6 \mathrm{c}$ \\
47 & $38.4 \mathrm{c}$ & $5.9 \mathrm{c}$ & $2.2 \mathrm{c}$ & $27.3 \mathrm{~b}$ & $7.3 \mathrm{~b}$ & $34.6 \mathrm{~b}$ \\
110 & $41.0 \mathrm{c}$ & $7.0 \mathrm{~b}$ & $2.3 \mathrm{c}$ & $22.8 \mathrm{c}$ & $4.1 \mathrm{c}$ & $26.9 \mathrm{c}$ \\
142 & $44.7 \mathrm{~b}$ & $6.9 \mathrm{~b}$ & $2.1 \mathrm{~d}$ & $21.2 \mathrm{c}$ & $3.7 \mathrm{c}$ & $24.8 \mathrm{c}$ \\
167 & $37.0 \mathrm{c}$ & $5.1 \mathrm{c}$ & $1.7 \mathrm{e}$ & $20.1 \mathrm{c}$ & $3.4 \mathrm{c}$ & 23.6 & $\mathrm{c}$ \\
195 & $44.8 \mathrm{~b}$ & $4.7 \mathrm{c}$ & $2.0 \mathrm{~d}$ & $20.7 \mathrm{c}$ & $3.5 \mathrm{c}$ & $24.3 \mathrm{c}$ \\
253 & $45.4 \mathrm{~b}$ & $5.9 \mathrm{c}$ & $2.2 \mathrm{c}$ & $21.4 \mathrm{c}$ & $3.8 \mathrm{c}$ & $25.3 \mathrm{c}$ \\
288 & $42.1 \mathrm{c}$ & $5.6 \mathrm{c}$ & $2.2 \mathrm{c}$ & $21.3 \mathrm{c}$ & $3.7 \mathrm{c}$ & $24.9 \mathrm{c}$ \\
Vanda & $38.5 \mathrm{c}$ & $7.2 \mathrm{~b}$ & $2.4 \mathrm{~b}$ & $18.0 \mathrm{c}$ & $2.8 \mathrm{c}$ & $20.8 \mathrm{c}$ \\
Luiza & $52.4 \mathrm{a}$ & $8.4 \mathrm{a}$ & $2.0 \mathrm{~d}$ & $34.3 \mathrm{a}$ & $9.0 \mathrm{a}$ & $43.3 \mathrm{a}$ \\
\hline CV (\%) & 8.3 & 11.3 & 5.8 & 10.9 & 20.3 & & 10.9 \\
\hline
\end{tabular}

Averages followed by the same letter in the column do not differ among each other by Scott-Knott test, at 5\% significance.

masses are in perpendicular direction to the chlorophyll contents, showing that these variables are not correlated. We could observe that an indication of the relationship between shoot fresh and dry masses and such relationship is proven from the correlation graph, where the correlation between fresh and dry masses was positive and significant at $0.1 \%$ probability, showing a value of 0.92 (Figures 2 and 3). Shoot dry mass also showed a significant positive correlation ( $5 \%$ probability) with the stem diameter (0.59). In the correlation analysis comparing the fresh mass with all the other evaluated variables, we could observe a significant correlation with only the shoot dry mass and negative correlation, not significant with chlorophyll a, b and total chlorophyll, though.

In relation to root dry and fresh masses, only the inbred line 47, Vanda and Luiza showed differences, with lowest values, being the root dry mass about 6 to $7 \%$ of fresh mass (Table $1)$. We verified a significant positive correlation at $0.1 \%$ probability between root dry and fresh masses, with a value of 0.9 (Figure 2). The root dry and fresh masses showed significant negative correlations at $5 \%$ probability showing chlorophyll $\mathrm{b}$ from $-0,6$ to $-0,59$ respectively.

The inbred lines 09, 27 and 288 showed the greatest number of leaves, with an average of $34,64 \%$ greater in relation to inbred lines 167 and 195, with an average of 21 leaves per plant (Table 1). Analyzing the PCA, the authors could observe that this variable has a relationship with chlorophyll content and with the stem diameter (Figure 1). Moreover, this relationship was also presented in the correlation analysis, where the variable number of leaves showed significant positive correlations at $5 \%$ probability with chlorophyll a (0.67), with the total chlorophyll (0.63) and with the stem diameter (0.7) (Figure 2 ). The number of lettuce leaves is one important trait, since the leaves are the product to be consumed when it comes to this vegetable, so that one genotype which shows a greater number of leaves stands out among the others. Ceccherini et al. (2020), evaluating crispleaf lettuce Vanda under hydroponic system, found 27 leaves per plant, approximately. The light interception, which will be converted into chemical energy, is facilitated when a greater number of leaves can be noticed; so, plants with more leaves will show a faster development, will be more vigorous and can be even early (Taiz et al., 2017).

The inbred lines 09 and 288 showed a plant $29 \%$ higher in relation to ones with shorter heights $(47,167)$. The leaf shapes influenced the plant height, so that, the variations found between the inbred lines 09 and 288 with inbred lines 47 and 167 were due to this factor. The inbred lines 47 and 167 showed circular leaf to enlarged transverse elliptical, which is a shape that gives the characteristic of shorter plants; the inbred lines 09 and 288 have narrow elliptical-shaped leaves, conferring taller size of plants (MAPA, 2019). The plant height showed significant positive correlation at $5 \%$ probability, with the shoot dry mass, $0.58 \mathrm{~g}$ (Figure $2)$. These results are in accordance with Ceccherini et al. (2020) who, evaluating the crispleaf Vanda under hydroponic system, found plants ranging from 19 to $28 \mathrm{~cm}$ plant $^{-1}$.

Luiza showed the longest root, 52.4 $\mathrm{cm}$, the other genotypes showed length from 37.0 to $45.4 \mathrm{~cm}$ plant $^{-1}$ (Table 1). Root length did not show any correlation with the other evaluated variables (Figures 1 and 2). Luiza also showed the highest value for stem length, since this is a romaine lettuce, whose measurements and size is different from crispleaf lettuce. Stem length is also relevant for selecting inbred lines for breeding programs, since it is directly related with the lettuce bolting. Thus, the shorter the length, more tolerant to early bolting. Therefore, the inbred lines evaluated in this study showed good tolerance to early bolting when 


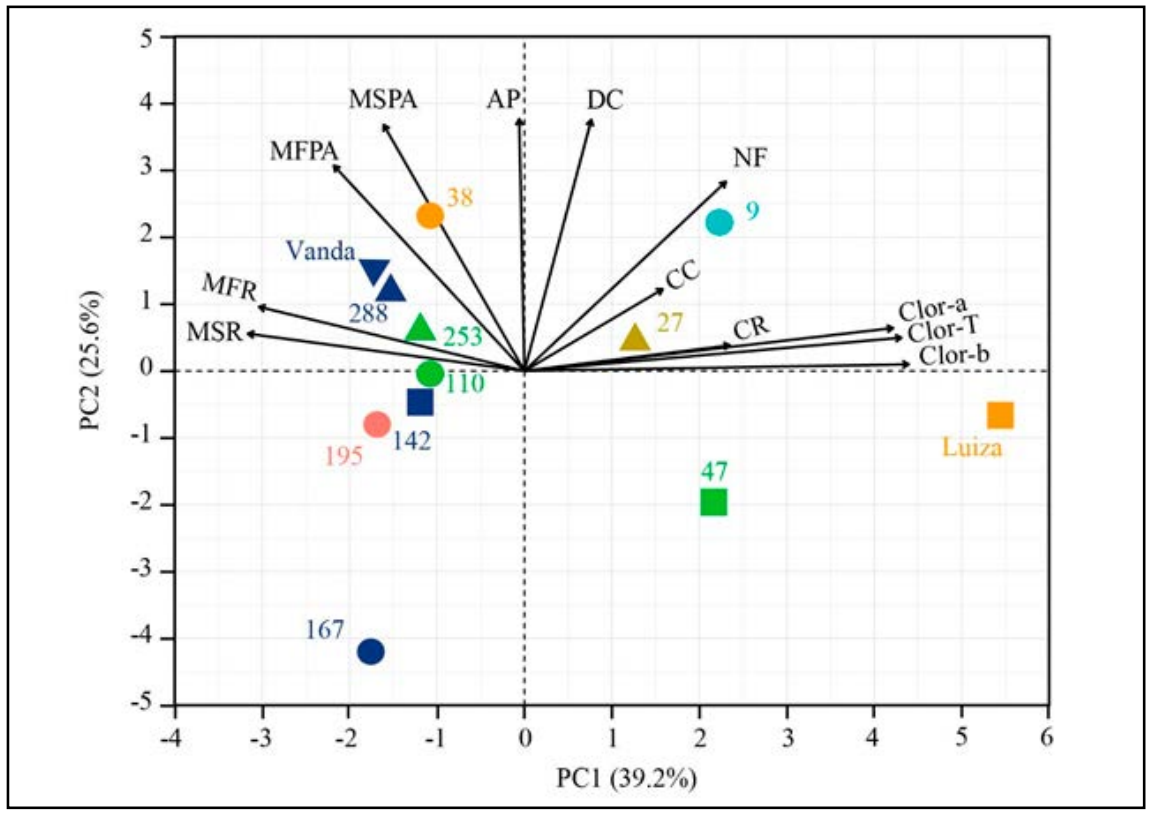

Figure 1. Principal component analysis (PCA) of the shoot fresh mass (MFPA), shoot dry mass (MSPA), plant height (AP), number of leaves (NF), chlorophyll a content (Clor-a), chlorophyll b content (Clor-b), total chlorophyll content (Clor-T), root length (CR), stem length (CC), stem diameter (DC), root fresh mass (MFR) and root dry mass (MSR) of lettuce genotypes $(09,27,38,47,110,142,167,195,253,288$, Luiza and Vanda) grown under hydroponic system. PC1: principal component 1; PC2: principal component 2 . It is possible to verify a positive correlation between the characteristics evaluated with parallel arrows, negative correlation with arrows in opposite directions and no correlation with perpendicular arrows. Araras, UFSCar, 2019.

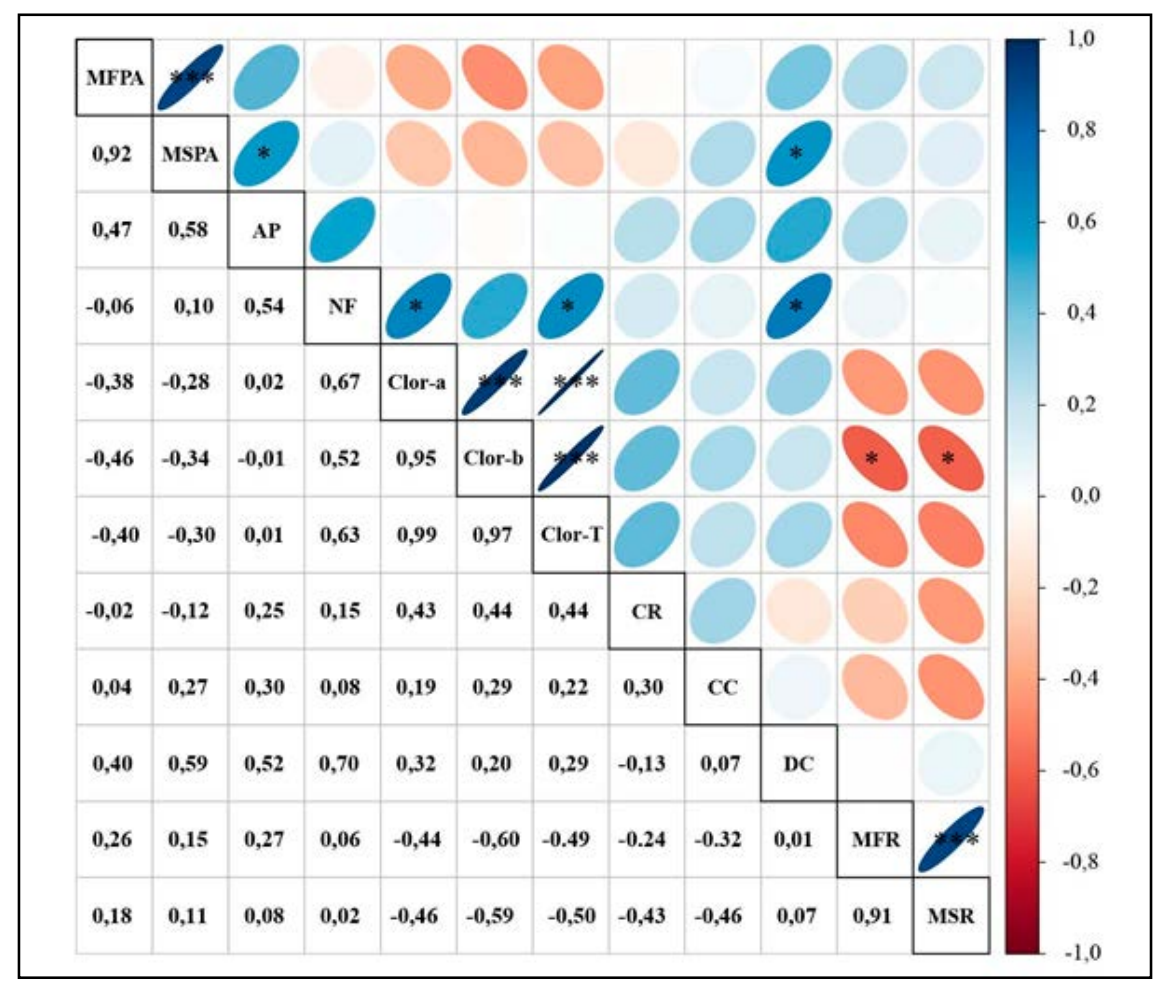

Figure 2. Correlations among the shoot fresh mass (MFPA), shoot dry mass (MSPA), plant height (AP), number of leaves (NF), chlorophyll a content (Clor-a), chlorophyll b content (Clor-b), total chlorophyll content (Clor-T), root lenght (CR), stem length (CC), stem diameter (DC), root fresh mass (MFR) and root dry mass (MSR) of lettuce genotypes grown under hydroponic system. Araras, UFSCar, 2019. compared to Vanda. Sediyama et al. (2009), comparing six marketable cultivars under hydroponic system in summer and winter, obtained stem length, during the summer, ranging from 6.4 to $14.6 \mathrm{~cm}$ and, in the winter, from 4.8 to $7.6 \mathrm{~cm}$, showing a relationship between temperature and bolting.

The larger the stem diameter, the easier the detachment of leaves. Silveira (2016) evaluated eight inbred lines of crispy head lettuce and two marketable cultivars and found similar results when comparing to this study, where Vanda showed $2.8 \mathrm{~cm}$. Costa et al. (2014) found similar values, where Vanda showed $2.6 \mathrm{~cm}$.

For total chlorophyll contents, the average of the genotypes showed ratio of $83 \%$ chlorophyll a to $17 \%$ chlorophyll b. Similar results were found by Souza et al. (2019), evaluating the chlorophyll content of "Crocantela" lettuce under hydroponic system; $78.4 \%$ consisted of chlorophyll a and $21.5 \%$ of chlorophyll $b$. These results are also in accordance with Gross (1991), who confirmed higher content of chlorophyll a in relation to chlorophyll b, about $75 \%$. The main photoreceptor in photosynthesis is chlorophyll, where, in vascular plants, chlorophyll a and b forms are the majority and, generally, in 3:1 order, respectively (Bhatla \& Manju, 2018). The inbred line 09 and Luiza showed the highest chlorophyll a content and Luiza the highest chlorophyll $b$ content, showing ratio between $a$ and $b$, approximately, 80 and $20 \%$, respectively (Table 1). The cultivars with lower content of chlorophyll a and $\mathrm{b}(38,110$, $142,167,195,253,288$, Vanda) showed ratio between a and b, approximately, 85 and $15 \%$, respectively. In relation to total chlorophyll, the inbred line 09 and Luiza showed an average 66\% higher in relation to the ones with the lowest content $(38,110,142,167,195,253$, 288, Vanda).

The ratio between chlorophyll a and $\mathrm{b}(\mathrm{a}: \mathrm{b})$ of the genotypes with the highest shoot fresh mass $(38,195,253$, and Vanda; a:b with value of, approximately, $6: 1)$ was higher than that of the ones with intermediate fresh mass $(9,27,110$, 142 and 288; ratio 5:1), and higher than that of the ones with the lowest fresh 


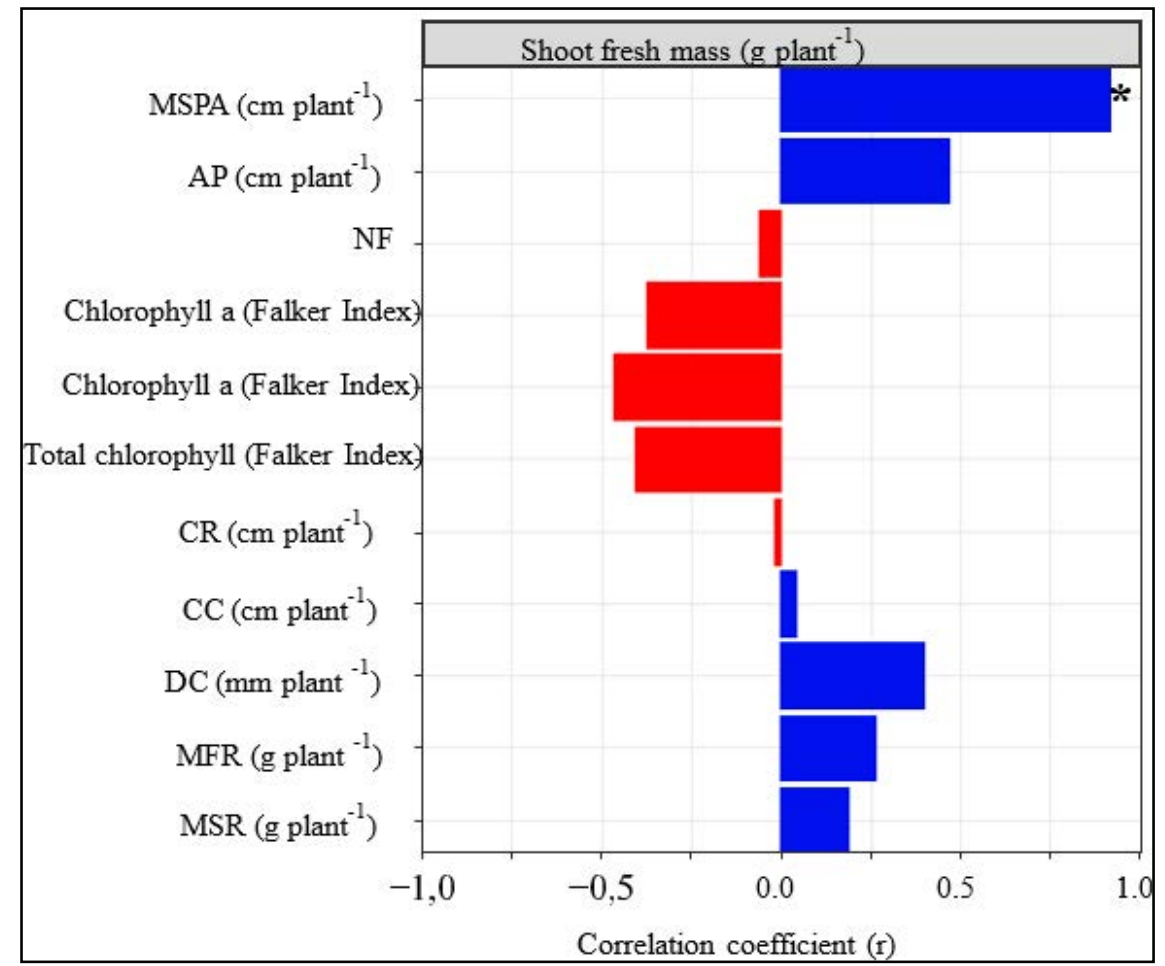

Figure 3. Correlation graph comparing the shoot fresh mass with the evaluated traits of shoot dry mass (MSPA), plant height (AP), number of leaves (NF), chlorophyll a content, chlorophyll b content, total chlorophyll content, root length (CR), stem length (CC), stem diameter (DC), root fresh mass (MFR) and root dry mass (MSR) of lettuce genotypes grown under hydroponic system. Araras, UFSCar, 2019.

mass (47, 167 and Luiza; ratio 4:1) (Table 1). A lower ratio a:b is related to smaller number of photosystem II reaction centers, and it can be related to a decline in the maximum electron transport capacity of this photosystem (Evans, 1988). Such decline is a possible explanation for the different a:b ratios between accessions with the highest and the lowest fresh mass.

Photosynthesis is dependent on the chlorophyll a in plants, and responsible for absorbing red and blue light (Johkan et al., 2010). Wang et al. (2016), evaluating the development of lettuce with different ratios between the red and blue lights, found that the highest chlorophyll content is able to contribute to a higher photosynthetic rate. However, the highest photosynthetic rate was not reverted to dry mass gain, since dry mass accumulation in lettuce plants depends not only on the photosynthetic rate, but on other factors, such as number of leaves, leaf area stomata and gas exchange.

Results similar to the ones found in this study were verified by Rosa et al. (2014), where green and purple oakleaf lettuce cultivated in hydroponic and conventional cultivation system, showed differences in chlorophyll contents. Green oakleaf lettuce had lower contents, around 50\% lower than purple oakleaf lettuce, however, its fresh mass production was higher; so the types of lettuce with higher chlorophyll content tend to have lower mass production. Corroborating this study, Cardoso et al. (2018) evaluated crispleaf, iceberg and butterhead types of lettuce in a protected environment, and verified that the iceberg lettuce showed the highest chlorophyll content; however, this lettuce was not the one which showed the highest mass production. No linear correlations were observed among plants containing different chlorophyll contents and fresh and dry mass of lettuce genotypes cultivated under hydroponic system.

The genotypes which have higher chlorophyll content show lower mass production capacity. This result is relevant for vegetable breeding programs, in order to select genotypes, taking into account consumer preference, physiological and agronomic effects.

\section{REFERENCES}

BHATlA, SC; MANJU, AL. 2018. Plant physiology, development and metabolism. Singapore: Springer. $1237 \mathrm{p}$.

CARDOSO, SS; GUIMARÃES, MA; LEMOS NETO, HS; TELLO, JPJ; DOVALE, JC. 2018. Morphological and productive aspects of lettuce in low altitude and latitude. Revista Ciência Agronômica 49: 644-652.

CASSETARI, LS; GOMES, MS; SANTOS, DC; SANTIAGO, WD; ANDRADE, J; GUIMARÃES, AC; SOUZA, JA; CARDOSO, MG; MALUF, WR; GOMES, LA. 2015. $\beta$-carotene and chlorophyll levels in cultivars and breeding lines of lettuce. Acta Horticulturae 1083: 469-473.

CECCHERINI, GJ; LIMA, TJL; SALA, FC. 2020. Different tray cell volumes for lettuce grown in conventional and hydroponic system. Ciência Rural 50: 1-6.

CONFEDERAÇÃO DA AGRICULTURA E PECUÁRIA DO BRASIL. 2017. Mapeamento e quantificação da cadeia produtiva das hortaliças. Brasília: CNA. 79p.

COSTA, JB; SALA, FC; CAMPOS, MBS; CUBA, RS. 2014. Efeito do tipo de perfil na produção de alface em sistema hidropônico sob telado. Revista Hidroponia 25: 18-20.

EVANS, JR. 1988. Acclimation by the thylakoid membranes to growth irradiance and the partitioning of nitrogen between soluble and thylakoid proteins. Australian Journal of Plant Physiology 15: 93-106.

FERRUZZI, MG; BLAKESLEE, J. 2007. Digestion, absorption, and cancer preventative activity of dietary chlorophyll derivatives. Nutrition Research 27: 1-12.

FILGUEIRA, FAR. 2008. Novo manual de olericultura: agrotecnologia moderna na produção e comercialização de hortaliças, 412p.

FONTANA, L; ROSSI, CA; HUBINGER, SZ; FERREIRA, MD; SPOTO, MH; SALA, FC; VERRUMA-BERNARDI, MR. 2018. Physicochemical characterization and sensory evaluation of lettuce cultivated in three growing systems. Horticultura Brasileira 36: 20-26.

FURLANI, PR. 1999. Hydroponic vegetable production in Brazil. Acta Horticulturae 481: 777-778.

GROSS, J. 1991. Pigments in vegetables, chlorophylls and carotenoids. New York: Van Nostrand Reinhold. 351p.

JOHKAN, M; SHOJI, K; GOTO, F; HASHIDA, S; YOSHIHARA, T. 2010. Blue light-emitting diode light irradiation of seedlings improves seedling quality and growth after transplanting in red leaf lettuce. HortScience 45: 1809-1814.

LIMA, MC; AMARANTE, L; MARIOT, MP; SERPA, R. 2011. Crescimento e produção de pigmentos fotossintéticos em Achillea millefolium $\mathrm{L}$. cultivada sob diferentes níveis 
de sombreamento e doses de nitrogênio. Ciência Rural 41: 45-50.

LIMA, TJL; GAZAFFI, R; CECCHERINI, GJ; MARCHI, L; MARTINEZ, M; FERREIRA, CG; SALA, FC. 2018. Volume of cells on trays influences hydroponic lettuce production. Horticultura Brasileira 36: 408-413.

MAPA - Ministério da agricultura pecuária e abastecimento. 2001. Instruções para execução dos ensaios de distinguibilidade, homogeneidade e estabilidade de cultivares de alface (Lactuca sativa L.). Available at http:// www.agricultura.gov.br/assuntos/insumosagropecuarios/insumos-agricolas/protecao-decultivar/olericolas. Accessed October 7, 2019.

PURQUERIO, LFV; MORAES, CC; FACTOR, TH; CALORI, AH. 2018. Bioeconomia: promoção da horticultura urbana do século XXI. O Agronômico 70: 6-19. (Boletim técnico-informativo IAC).

R CORE TEAM. 2018. R: A language and environment for statistical computing. $\mathrm{R}$ Foundation for Statistical Computing, Vienna, Austria. Available at $<$ https://www.r-project. org/>. Accessed August 20, 2019.
ROSA, AM; SEÓ, HLS; VOLPATO, MB; FOZ, NV; SILVA, TC; OLIVEIRA, JLB; PESCADOR R; OGLIARI, JB. 2014. Production and photosynthetic activity of Mimosa Verde and Mimosa Roxa lettuce in two farming systems. Revista Ceres 61: 494-501.

SALA, FC. 2011. Aspectos históricos do melhoramento para os segmentos varietais de alface no Brasil. Resumo expandido em Horticultura Brasileira. In: $51^{\circ}$ Congresso Brasileiro de Olericultura 29. Viçosa: ABH. S5813-S5827.

SALA, FC; COSTA, CP. 2012. Retrospectiva e tendência da alfacicultura brasileira. Horticultura Brasileira 30: 187-194.

SALA, FC; COSTA, CP. 2014. "Brunela": cultivar de minialface crocante tropicalizada. Resumo expandido em Horticultura Brasileira. In: $53^{\circ}$ Congresso Brasileiro de Olericultura 31 : S1839-1841.

SEDIYAMA, MAN; PEDROSA, MW; SALGADO, LT; PEREIRA, PC. 2009. Desempenho de cultivares de alface para cultivo hidropônico no verão e no inverno. Cientifica: 37: 98-106.
SILVA, E; FERREIRA, EA; FERREIRA, MR. 2016. Desempenho da alface americana sob a aplicação de adubos químico e orgânico. Ciencia et Praxis 9: 21-24.

SILVEIRA, FCG. 2016. Desempenho de genótipos de alface-crespa em diferentes ambientes de cultivo, no município de Igarapava-SP. Igarapava-SP: Unesp. 34p (M.Sc. dissertation)

SOUZA, PF; BORGHEZAN, M; ZAPPELINI, J; CARVALHO, LR; REE, J; BARCELOSOLIVEIRA, JL; PESCADOR, R. 2019. Physiological differences of 'Crocantela' lettuce cultivated in conventional and hydroponic systems. Horticultura Brasileira 37: 101-105.

TAIZ, L; ZEIGER, E; MØLLER, IM; MURPHY, A. 2017. Fisiologia e desenvolvimento vegetal. Porto Alegre: Artmed. 858p.

WANG, J; LU, W; TONG, Y; YANG, Q. 2016. Leaf morphology, photosynthetic performance, chlorophyll fluorescence, stomatal development of lettuce (Lactuca sativa L.) exposed to different ratios of red light to blue light. Frontiers in Plant Science 7: 1-10. 